\title{
IMPLEMENTASI MODEL PEMBELAJARAN CORE DAN KENDALANYA pADA MATERI TEKS GeRITA FABEL
}

\author{
HERMANUDIN \\ SMP Negeri 10 Bengkulu Tengah \\ hermanudinwahin@gmail.com \\ Pertama Diterima: 27 Mei 2019 \\ Bukti Akhir Diterima: 5 Juni 2019
}

\begin{abstract}
Abstrak
Tujuan penelitian ini adalah untuk mendeskripsikan implementasi model pembelajaran CORE (Connecting, Organizing, Reflecting, Extending) pada membaca pemahaman materi teks cerita fabel dan mengenali hambatan-hambatan pelaksanaan serta cara mengatasinya. Penelitian ini adalah penelitian tindakan. Penelitian dilakukan di kelas VII A SMP Negeri 10 Bengkulu Tengah. Data penelitian ini bersumber dari aktivitas pembelajaran siswa di kelas dan guru mata pelajaran bahasa Indonesia. Teknik pengumpulan data melalui observasi pembelajaran di kelas. Taknik analisis data adalah analisis deskriptif dengan mendeskripsikan proses pembelajaran yang berlangsung di kelas untuk mengenali hambatan dan memberi solusi penyelesaiannya. Hasil penelitian membuktikan bahwa model CORE dapat meningkatkan aktivitas pembelajaran siswa pada pembelajaran membaca pemahaman materi teks cerita fabel dan terdapat beberapa hambatan dalam pelaksanaannya.
\end{abstract}

Kata Kunci: Model CORE, membaca pemahaman, cerita fabel.

\begin{abstract}
The purpose of this study is to describe the implementation of the CORE learning model (Connecting, Organizing, Reflecting, Extending) on reading the understanding of fable story text material and recognizing the obstacles to implementation and how to overcome them. This research is an action research. The study was conducted in class VII A Middle School 10 Bengkulu Tengah. The data of this study were sourced from student learning activities in class and Indonesian language teacher. Data collection techniques through observation of learning in class. The technique of data analysis is descriptive analysis by describing the learning process that takes place in class to identify obstacles and provide solutions to their resolution. The results of the study prove that the CORE model can increase student learning activities in learning to read comprehension of fable story text material and there are several obstacles in its implementation.
\end{abstract}

Keywords: CORE model, reading comprehension, fable story. 


\section{PENDAHULUAN}

Model pembelajaran merupakan kerangka konseptual berupa pola prosedur sistematik yang dikembangkan berdasarkan teori dan digunakan dalam mengorganisasikan proses belajar mengajar untuk mencapai tujuan belajar, Sani (2013:89). Model pembelajaran terkait dengan pemilihan strategi dan pembuatan struktur metode, keterampilan, dan aktivitas peserta didik. Ciri utama sebuah model pembelajaran adalah adanya tahapan atau sintak pembelajaran.

Asih (2016:138), mendefinisikan model pembelajaran adalah bentuk pembelajaran yang tergambar dari awal sampai akhir, yang disajikan secara khas oleh guru di kelas. Pengertian model disini hampir mendekati pengertian strategi pembelajaran. Sementara itu, Abidin (2014: 117) menyatakan bahwa model pembelajaran adalah suatu konsep yang membantu menjelaskan proses pembelajaran, baik menjelaskan pola pikir maupun pola tindakan pembelajaran tersebut.

Dari beberapa pendapat tersebut, model pembelajaran dapat diartikan suatu kerangka konseptual yang tergambar dari awal sampai akhir dari proses pembelajaran untuk mencapai tujuan belajar.

Cerita fabel termasuk termasuk genre teks naratif dengan tujuan sosial bercerita dengan sudut pandang moral secara eksplisit. Fabel termasuk jenis cerita fiksi, bukan kisah tentang kehidupan nyata.Cerita fabel sering juga disebut cerita moral karena pesan yang ada di dalam cerita fabel berkaitan erat dengan moral.

Pemilihan model pembelajaran yang tepat oleh guru dapat membantu para siswa dalam mencapai tujuan belajar. Terdapat beberapa model pembelajaran yang kini berkembang, salah satunya adalah model pembelajaran CORE (connecting, organizing, reflecting, extending). Materi teks cerita fabel dapat diajarkan dengan menggunakan model pembelajaran CORE.

Permasalahan yang diangkat dalam penelitian ini adalah bagaimana langkah-langkah pelaksanaan pembelajaran materi teks cerita fabel dengan model CORE, apa saja kendala dalam pelaksanaan pembelajaran materi teks cerita fabel dengan model pembelajaran CORE serta bagaimana cara mengatasinya.

Model pembelajaran CORE (connecting, organizing, reflecting, extending) adalah model pembelajaran yang menekankan kemampuan berpikir siswa untuk menghubungkan, mengorganisasikan, mendalami, mengelola, dan mengembangkan informasi yang didapat. Menurut Shoimin (2014: 39), model pembelajaran CORE (connecting, organizing, reflecting, extending) adalah model pembelajaran yang dapat membantu siswa dalam memahami suatu materi pelajaran.

Menurut Suyatno (2009: 67), model pembelajaran CORE memiliki empat aspek kegiatan yaitu (1) connecting yaitu kegiatan mengoneksikan pengetahuan baru dengan pengetahuan lama, (2) organizing yaitu kegiatan untuk mengorganisasikan ide-ide untuk memahami materi, (3) reflecting yaitu kegiatan memikirkan kembali, mendalami dan menggali informasi yang sudah didapat, (4) extending yaitu kegiatan untuk megembangkan, memperluas, menggunakan dan menemukan.

Miller dan Calfee (2004) mengemukakan: 
The CORE Model incorporates four elements: Connect, Organize, Reflect, and Extend. The elements can be used for designing a sequence of instructional activities. Students first connect what they already know about a topic to new science content or experience. Then they organize information from multiple sources into coherent packages. They then reflect on the collection of "stuff" by discussing it with others in preparation for the writing task. Finally, completion of the project serves to "stretch" or extend the learning.

Model CORE menggabungkan empat elemen yaitu Connect, Organize, Reflect, and Extend. Unsur-unsur dapat digunakan untuk merancang urutan kegiatan pembelajaran. Siswa pertama-tama menghubungkan apa yang sudah mereka ketahui tentang suatu topik ke konten atau pengalaman sains baru. Kemudian mereka mengatur informasi dari berbagai sumber menjadi paket yang koheren. Mereka kemudian merenungkan koleksi "bahan" dengan mendiskusikannya dengan orang lain sebagai persiapan untuk tugas menulis. Akhirnya, penyelesaian berfungsi untuk "melebarkankan" atau memperluas pembelajaran.

Model pembelajaran CORE merupakan model pembelajaran yang mencakup empat aspek kegiatan yaitu connecting, organizing, reflecting, dan extending. Empat aspek kegiatan tersebut digunakan untuk menghubungkan informasi lama dengan informasi baru, mengorganisasikan sejumlah materi yang bervariasi, merefleksikan segala sesuatu yang peserta didik pelajari, dan mengembangkan bahan atau materi pembelajaran. Adapun keempat aspek tersebut adalah:

1. Connecting: Merupakan kegiatan mengoneksikan informasi lama dan informasi baru dan antar konsep. Siswa mampu mengaitkan atau menghubungkan informasi-informasi yang baru di dapat dalam kegiatan pembelajaran dengan informasi-informasi lama yang sudah dimiliki siswa.

2. Organizing: Merupakan kegiatan mengorganisasikan ide-ide untuk memahami materi. Siswa menentukan informasi yang sedang dicari, informasi yang sudah dimiliki, dan keterkaitan antara informasi yang ditemukan dengan informai yang sudah dimiliki siswa.

3. Reflecting: Merupakan kegiatan memikirkan kembali, mendalami, dan menggali informasi yang sudah didapat. Pada kegiatan ini siswa memikirkan kembali informasi-informasi yang sudah didapatkan benar atau salah atau mungkin masih te rdapat kekurangan.

4. Extending: Merupakan kegiatan untuk mengembangkan, memperluas, menggunakan, dan menemukan. Pada tahap ini siswa dapat memperluas pengetahuan atau informasi yang didapat atau dimiliki selama proses berlangsung.

Dari beberapa pendapat tersebut, model CORE dapat dipahami sebagai suatu model pembelajaran yang memiliki desain mengonstruksi kemampuan siswa dengan cara menghubungkan dan mengorganisasikan pengetahuan, kemudian memikirkan kembali konsep yang sedang dipelajari dan memperluas pemahaman materi dengan pengetahuan di luar teks.

Menurut Ngalimun (2014:171), sintak pembelajaran model CORE adalah $(C)$ koneksi informasi lama-baru dan antar konsep, $(O)$ organisasi ide untuk memahami materi, $(R)$ memikirkan kembali, mendalami, dan menggali, $(E)$ mengembangkan, memperluas, menggunakan, dan menemukan. 
Curwen et al. (2010:133) menggambarkan siklus model CORE yang dikutip dari Miller dan Calfee sebagai berikut:

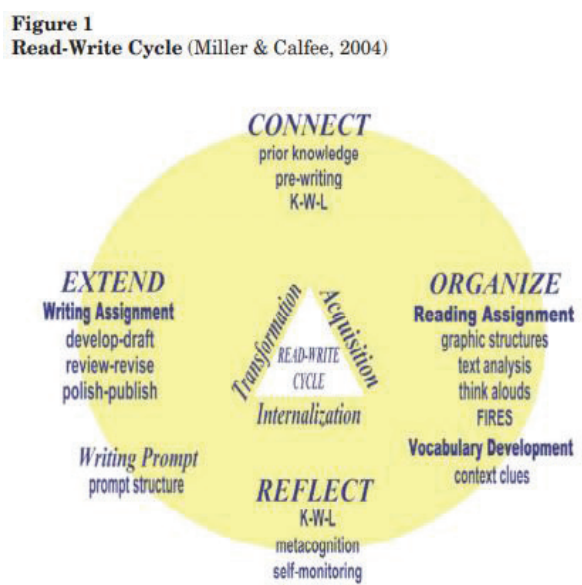

Ket: siklus model CORE dari Miller dan Calfee dalam Curwen et al, Volume 19, Number 2, Fall (2010)

Dalam model ini aktivitas berpikir sangat ditekankan kepada siswa. Siswa dituntut untuk dapat berpikir kritis terhadap informasi yang didapatnya. Kegiatan mengoneksikan konsep lama-baru siswa dilatih untuk mengingat informasi lama dan menggunakan informasi/konsep lama tersebut untuk digunakan dalam informasi/konsep baru. Kegiatan mengorganisasikan ide-ide, dapat melatih kemampuan siswa untuk mengorganisasikan, mengelola informasi yang telah dimilikinya. Kegiatan refleksi, merupakan kegiatan memperdalam, menggali informasi untuk memperkuat konsep yang telah dimilikinya. Extending, dengan kegiatan ini siswa dilatih untuk mengembangkan, memperluas informasi yang sudah didapatnya dan menggunakan informasi dan dapat menemukan konsep dan informasi baru yang bermanfaat.

Teks fabel menurut Tim Pendongeng SPA Yogyakarta (2010:12), adalah cerita tentang dunia hewan atau tumbuh-tumbuhan yang seolah-ołah bisa berbicara seperti umumnya manusia. Cerita fabel termasuk termasuk genre teks naratif dengan tujuan sosial bercerita dengan sudut pandang moral secara eksplisit. Cerita fabel biasanya menceritakan tentang kehidupan di alam mereka, di mana mereka hidup dan tinggal.

Menurut Wahono dalam Handayani (2018), Fabel ialah suatu bentuk cerita pendek dimana dalam cerita tersebut terdapat penggambaran watak serta budi pekerti manusia diibaratkan dengan binatang. Dalam teks cerita fabel menceritakan kehidupan sehari-hari manusia yang digambarkan oleh tokoh-tokoh binatang seperti halnya dalam kehidupan nyata. Namun, cerita tersebut bukanlah cerita nyata melainkan cerita rekaan (khayalan). Cerita tersebut dibuat untuk menghibur pembaca atau penonton, selain itu yang paling penting adalah selalu terdapat nilai-nilai karakter yang terdapat di setiap cerita.

Fabel termasuk jenis cerita fiksi, bukan kisah tentang kehidupan nyata.Cerita fabel sering juga disebut cerita moral karena pesan yang ada di dalam cerita fabel berkaitan erat dengan moral. Teks cerita fabel digunakan sebagai sarana untuk menyampaikan pesan-pesan dan nilai moral kepada pembaca, dengan tujuan agar pembaca tidak mudah tergoda untuk melakukan tindakan tercela. 


\section{METODOLOGI PENELITIAN}

Penelitian ini adalah penelitian tidakan yaitu suatu bentuk penelitian yang bersifat reflektif dengan melakukan tindakan-tindakan tertentu agar dapat memperbaiki dan meningkatkan kualitas praktik-praktik pembelajaran di kelas menjadi lebih profesional. Penelitian ini dilaksanakan di kelas VII A SMP Negeri 10 Bengkulu Tengah. Kelas VII A berjumlah 23 siswa yang terdiri dari 11 siwa laki-laki dan 12 siswa perempuan. Penelitian dilakukan pada jam pelajaran bahasa Indonesia. Penelitian dilakukan pada tanggal 21 Maret 2019 pukul 13.00 sampai dengan 14.30 selama 3 jam pelajaran.

Metode penelitian ini adalah metodode deskriptif. Menurut Sukmadinata (2011:54) penelitian deskriptif adalah suatu metode penelitian yang ditujukan untuk menggambarkan fenomenafenomena yang ada, yang berlangsung pada saat ini atau saat yang lampau. Penelitian deskriptif menggambarkan suatu kondisi apa adanya. Mahmud (2011:100) mendifinisikan penelitian deskriptif adalah suatu penelitian yang diupayakan untuk mencandra atau mengamati permasalahan secara sistematis dan akurat mengenai fakta dan sifat objek tertentu. Penelitian deskriptif ditujukan untuk memaparkan dan menggambarkan atau memetakan fakta-fakta berdasarkan cara pandang atau kerangka berpikir tertentu.

Desain penelitian ini adalah mengamati proses pembelajaran di kelas ketika guru memberikan pelajaran materi teks cerita fabel. Data penelitian ini adalah data observasi pembelajaran membaca teks cerita fabel yang dilakukan siswa dan data observasi kegiatan mengajar yang dilakukan guru. Data observasi berupa pengamatan terhadap proses pembelajaran yang berlangsung di kelas diperoleh dengan menggunakan lembar observasi. Data ini digunakan untuk mengetahui aktivitas pembelajaran membaca pemahaman teks cerita fabel. Data observasi diperoleh dengan mengisi lembar observasi kegiatan pembelajaran yang berlangsung di kelas. Observer dalam penelitian ini adalah peneliti dan guru mata pelejaran.

Hasil observasi pembelajaran dideskripsikan untuk menggambarkan proses pembelajaran yang berlangsung secara keseluruhan dari awal sampai akhir pembelajaran. Indikator keberhasilan penelitian ini adalah terdeskripsinya proses pembelajaran materi membaca pemahaman cerita fabel dengan menggunakan model pembelajaran CORE menemukan kendala dalam pelaksanaanya dan mengatasi kendala yang ditemukan.

\section{HASIL PENELITIAN DAN PEMBAHASAN}

Materi teks cerita fabel masuk dalam pelajaran bahasa Indonesia kurikulum 2013 di kelas VII dengan kompetensi dasar sebagai berikut:

3.11 Mengidentifikasi informasi tentang fabel/legenda daerah setempat yang dibaca dan didengar.

4.11 Menceritakan kembali isi fabel/legenda daerah setempat.

3.12 Menelaah struktur dan kebahasaan fabel/legenda daerah setempat yang dibaca dan didengar

4.12 Memerankan isi fabel/legenda daerah setempat yang dibaca dan didengar. 
Materi teks cerita fabel ini banyak mengandung nilai-nilai moral yang baik, patut diteladani dan sejalan dengan penguatan pendidikan karakter yang sedang digaungkan dalam kurikulum 2013.Materi teks cerita fabel merupakan salah satu materi yang mengandung misi menyampaikan pesan-pesan moral melalui cerita.

Materi teks cerita fabel yang diajarkan adalah membaca teks cerita fabel yang berjudul "Dongeng Harimau, Petapa, dan Anjing Hutan yang cerdik" karya Joseph Jacobs dalam Budaya Nusantara https://www.budayanusantara.web.id/2015/05/dongeng-harimau-petapa-dan-anjinghutan.html. Materi ini diajarkan dengan menggunakan model pembelajaran CORE, metode diskusi dan pendekatan yang digunakan adalah pendekatan saintifik.

Dalam melaksanakan pembelajaran menggunakan model CORE, garis besar tahapan-tahapan pembelajarannya adalah sebagai berikut:

Tahap Pembelajaran Menghubungkan Pengetahuan (Connecting Knowledge)

Mengorganisasikan informasi (Organizing Information)

Refleksi dalam Kegiatan Belajar (Reflecting on Learning)

Memperluas Pengalaman (Extendingthe Experience)
Kegiatan Siswa

a. mengingat kembali (recall), membuat mata rantai (Link), dan merangkai ideide. (Bruning, Schraw, dan Norby, 2011:205)

b. mengingat kembali tanggal atau fakta atau daftar informasi tertentu dan sekumpulan instruksi (Caine dan Caine, 1997: 41)

c. mendengarkan, membaca, mencium, merasakan, dan menulis (Henson dan Eller, 1999: 249)

a. mengumpulkan fakta-fakta dan mengorganisasikan informasi-informasi baru (Bruning, Schraw, dan Norby, 2011: 205)

b. membuat peta konsep (Novak dan Canas, 2008: 1)

a. menyajikan, mengatur, menjelaskan, dan mempertahankan ide (Bruning, Schraw, dan Norby, 2011: 205)

b. mengalami, menginterpretasikan pengalaman secara spontan, mengidentifikasi masalah atau pertanyaan yang didasarkan pada pengalaman, menghasilkan penjelasan yang mungkin untuk masalah atau pertanyaan yang diajukan, merumuskan hipotesis, dan bereksperimen atau menguji hipotesis yang dipilih. (Rodgers, 2002: 851).

a. membahas topik-topik baru lainnya yang relevan (Dymock, 2005: 2)

b. mencari jawaban dari pertanyaan yang mereka ajukan sendiri (Bruning, Schraw, dan Norby, 2011: 205)

Tahapan-tahapan pembelajaran tersebut dapat dideskripsikan dalam langkah kegiatan pembelajaran dengan menggunakan model pembelajaran CORE dan metode pembelajaran dengan diskusi sebagai berikut:

Pada kegiatan pendahuluan, pesertadidik berdoa sebelum belajar dipimpin oleh ketua kelas. Kemudian guru mengecek kehadiran peserta didik dan meminta peserta didik untuk mempersiapkan perlengkapan dan peralatan belajar yang diperlukan. Peserta didik kemudian menerima informasi tentang pembelajaran yang akan dilaksanakan pada kegiatan pembelajaran hari ini. Peserta didik menerima informasi tentang kompetensi dasar, ruang lingkup materi, tujuan pembelajaran, manfaat pembelajaran, langkah pembelajaran, metode penilaian yang akan dilaksanakan. Guru memberikan apersepsi dengan bertanya pada siswa untuk mencari informasi tentang cerita fabel yang pernah didengar atau dibaca. Kegiatan ini merupakan bagian dari Conecting, yaitu menghubungkan pengetahuan yang sudah dimiliki siswa dengan pengetahuan yang akan dibangun.

Pada kegiatan inti pembelajaran, guru membagi peserta didik menjadi beberapa kelompok yang terdiri 4-5 orang. Setelah kelompok terbentuk dan siswa sudah duduk pada kelompoknya masing- 
masing, kemudian guru menayangkan video cerita fabel yang berdurasi kurang dari 5 menit, peserta didik memperhatikan tayangan video tersebut. Setelah tayangan video selesai, guru bertanya jawab dengan siswa tentang cerita yang baru saja ditayangkan. Terjadi diskusi singkat tentang cerita yang baru ditonton.

Kegiatan pembelajaran dilanjutkan dengan peserta didik diberikan teks cerita fabel. Peserta didik mengamati dan membaca teks cerita dalam hati. Guru memberikan kesempatan kepada siswa untuk membaca teks cerita fabel. Setelah peserta didik selesai membaca, guru memberikan kesempatan kepada peserta didik untuk mengungkapkan pengalaman pribadinya berkenaan dengan cerita yang baru dibacanya. Peserta didik bertanya jawab tentang isi cerita fabel yang dibacanya dan menghubungkannya dengan pengalaman pribadi masing-masing. Kegiatan ini merupakan bagian dari Connecting dalam model pembelajaran CORE.

Kegiatan selanjutnya adalah guru membagikan lembar kerja siswa (LKS) sebagai bahan diskusi peserta didik. LKS berisi pertanyaan tentang isi cerita fabel, seperti: tokoh cerita dan karakter masing-masing tokoh, latar cerita, urutan peristiwa dalam cerita, pesan-pesan moral dari cerita dan menyimpulkan isi cerita. Peserta didik berdiskusi dalam kelompok masing-masing untuk menjawab LKS yang dibagikan. Jawaban-jawaban dari pertanyaan LKS merupakan bagian dari mengorganisasikan informasi dalam bacaan atau Organizing dalam model pembelajaran CORE, yaitu peserta didik menggorganisasikan informasi yang ada dalam bacaan untuk memahami isi bacaan. Selama siswa berdiskusi dalam kelompok, guru berkeliling mencermati peserta didik berdiskusi kelompok dan membantu berbagai kesulitan yang dialami peserta didik serta memberikan kesempatan untuk mempertanyakan hal-hal yang belum dipahami.

Setelah siswa selesai berdiskusi dalam kelompok, kegiatan berikutnya adalah peserta didik mempresentasikan hasil kerja kelompok ke depan kelas. Masing-masing kelompok diberikan kesempatan yang sama untuk mempresentasikan hasil kerja kelompoknya. Kelompok laindiberikan kesempatan untuk menanggapi hasil kerja kelompok yang tampil. Terjadi diskusi kelas dan perdebatan dalam siswa mempresentasikan hasil kerja kelompoknya.Kegiatan ini dalam model pembelajaran CORE disebut dengan Reflecting, yaitu merefleksikan hasil diskusi atau hasil kerja kelompok menurut pendapat dan pandangan kelompoknya masing-masing.

Kegiatan berikutnya adalah guru memandu peserta didik untuk melakukan eksplorasi, yaitu mengaitkan isi cerita yang dipelajari dengan kehidupan nyata di tengah masyarakat.Memandu peserta didik untuk dapat menemukan orang-orang yang berkarakter seperti dalam tokoh cerita, menemukan pelajaran moral yang dapat dijadikan contoh dalam kehidupan sehari-hari, menemukan pelajaran moral yang tidak baik dan tidak pantas ditiru dari cerita.Kegiatan ini dalam model pembelajaran CORE disebut dengan Extending, yaitu kegiatan untuk megembangkan, memperluas, menggunakan dan menemukan pengalaman baru dari hasil pembelajaran di kelas.

Pada kegiatan penutup, guru memberikan bantuan kepada peserta didik dalam mengambil hikmah dari cerita fabel yang dipelajari. Peserta didik merangkum pesan-pesan moral yang bisa dipetik dari cerita. Peserta didik dengan bimbingan guru dapat mengaitkan, merumuskan, dan menyimpulkan tentang hakikat pendidikan moral yang mau disampaikan lewat cerita fabel. Peserta didik melakukan refleksi, membuat kesimpulan secara lengkap, dan komprehensif tentang pembelajaran yang baru berlangsung. Guru memberikan apresiasi atas partisipasi semua peserta 
didik. Guru memberikan tugas mandiri sebagai pelatihan keterampilan dalam menentukan ciri, isi, dan pengembngan cerita fabel. Untuk memberi penguatan materi yang telah dipelajari, guru memberikan arahan untuk mencari referensi terkait materi yang telah dipelajari baik melalui bukubuku di perpustakaan atau mencari di internet. Guru dan peserta didik menutup pembelajaran.

Hasil penelitian membuktikan bahwa pembelajaran membaca pemahaman dengan menggunakan model CORE ternyata dapat meningkatkan hasil belajar membaca pemahaman siswa. Hal ini dapat dibuktikan dari hasil evaluasi pembelajaran membaca pemahaman dengan menggunakan model CORE siswa memperoleh nilai rata-rata 82,80, jauh di atas rata-rata hasil belajar membaca pemahaman dengan model konvensional yang memperoleh nilai rata-rata 69,79. Hasil pembelajaran dengan model CORE menunjukkan peningkatan yang sangat signifikan jika dibandingkan dengan hasil pembelajaran membaca pemahaman dengan model konvensional.

Hasil observasi pembelajaran materi membaca cerita fabel dengan menggunakan model pembelajaran CORE dapat dideskripsikan sebagai berikut:

Hasil observasi aktivitas pembelajaran menunjukkan hasil yang baik. Pada tahap pendahuluan pembelajaran, peserta didik masuk kelas tepat waktu, memberi salam kepada guru, sudah menyiapkan perlengkapan belajar, tidak melakukan pekerjaan lain yang akan mengganggu proses belajar, menciptakan suasana kelas yang tenang. Peserta didik sudah berani menjawab pertanyaan prasyarat dari guru.

Dari aspek antusiasme peserta didik dalam mengikuti kegiatan pembelajaran menunjukkan proses pembelajaran yang berjalan dengan aktif. Peserta didik menyimak informasi yang disampaikan oleh guru, tidak mengobrol dengan teman pada saat guru menjelaskan, memperhatikan materi yang disampaikan guru, sudah mampu menghubungkan pengetahuan baru dengan pengetahuan lama yang sudah dimiliki (Connecting). Peserta didik yang pada awalnya belum berani memberikan tanggapan terhadap apa yang disampaikan guru mulai menunjukkan keberanian memberikan tanggapan terhadap hal yang disampaikan guru. Peserta didik memahami informasi yang disampaikan guru (Organizing). Peserta didik yang pada awalnyabelum aktif bertanya kalau ada hal-hal yang belum dimengerti sudah mulai menunjukkan keberanian untuk bertanya kalau ada yang belum dimengerti.Peserta didik sudah mengerjakan tugas atau latihan dengan sungguhsungguh. Peserta didik pada awalnya belum berani menjawab pertanyaan temannya sudah muncul keberanian untuk menjawab pertanyaan yang diajukan temannya. Peserta didik sudah mau mengemukakan pendapat, mengerjakan LKS yang diberikan, dan mampu mengaitkan isi cerita fabel dengan kehidupan dunia nyata di tengah masyarakat (Extending).

Dalam kegiatan diskusi menunjukkan peningkatan yang baik. Peserta didik yang di awal diskusi belum berani mengemukakan pendapat, mulai aktif mengikuti diskusi dan berani mengajukan pendapat. Pada awal diskusi belum berani mengajukan pertanyaan ketika ada yang presentasi, mulai berani mengajukan pertanyaan. Pada awal presentasi pertanyaan muncul dari orang-orang tertentu saja mulai muncul pertanyaan dari peserta didik yang lain dan tidak dimdominasi orang tertentu lagi. Pada awal diskusi hanya siswa tertentu yang mau menjawab pertanyaan yang muncul, setelah diskusi berjalan mulai berani menjawab pertanyaan yang muncul dalam diskusi dan tidak didominasi oleh siswa tertentu saja. Siswa mengemukakan pendapat dengan menggunakan bahasa yang baik, menghargai pendapat temannya yang berbeda. 
Dalam aktivitas menutup kegiatan pembelajaran peserta didik mampu menarik kesimpulan materi yang telah diberikan, mencatat kesimpulan dan merangkum materi yang baru dipelajari. Peserta didik mendengarkan umpan balik dan penguatan dari guru mengenai teks cerita fabel yang baru berlangsung.

Kendala-kendala yang dialami peneliti ketika proses belajar mengajar berlangsung dengan menggunakan model pembelajaran CORE, metode mengajar dengan diskusi adalah sebagai berikut:

1. Kekurangan waktu untuk presentasi hasil diskusi

Proses belajar mengajar dengan menggunakan model pembelajaran CORE memerlukan waktu yang tidak sedikit. Metode mengajar yang digunakan adalah metode diskusi. Metode diskusi memerlukan lebih banyak waktu untuk siswa melakukan kegiatan diskusi dalam kelompok dan melakukan presentasi hasil kerja kelompok. Untuk kegiatan diskusi kelompok memerlukan waktu yang banyak, begitu juga untuk kegiatan presentasi hasil kerja kelompok memerlukan waktu yang tidak sedikit. Hal ini berdampak ada hasil kerja siswa yang tidak dapat dipresentasikan dalam diskusi kelas atau ada ketidaktuntasan pembahasan dalam diskusi. Untuk mengatasi keterbatasan waktu ini, guru harus dapat mengatur efisiensi waktu dalam setiap tahapan kegiatan proses pembelajaran. Guru harus membatasi waktu untuk siswa berdiskusi kelompok dan membatasi waktu presentasi hasil kerja kelompok. Guru harus mengatur waktu untuk setiap langkah kegiatan pembelajaran, jangan membiarkan siswa untuk mengulur-ulur waktu ketika diskusi kelompok, dan jangan membiarkan perdebatan berlangsung terlalu lama. Guru harus konsisten dengan kesepakatan awal tentang efisiensi waktu.

2. Kegiatan diskusi didominasi oleh siswa tertentu

Dalam diskusi yang dilakukan pada saat presentasi hasil kerja kelompok, pembicaraan didominasi oleh orang-orang tertentu saja. Pembicaraan dikuasai oleh siswa-siswa yang terampil berbicara dan berkemampuan baik, siswa yang lain lebih banyak jadi pendengar dan bersifat pasif. Perdebatan terjadi antar orang-orang tertentu, begitu juga ketika bertanya dan menjawab pertanyaan dilakukan oleh orang-orang tertentu saja. Untuk mengatasi hal tersebut, guru sebaiknya mengatur alur pembicaraan dan membatasi dominasi siswa yang terampil dan berkemampuan baik, memberikan kesempatan kepada siswa lain untuk bertanya dan menjawab pertanyaan, memberi semangat dan dorongan agar siswa yang cenderung pendiam mau berbicara. Guru dapat membangkitkan semangat siswa dengan memberikan penilaian proses ketika kegiatan diskusi berlangsung. Penilaian ini harus disampaikan kepada siswa agar mereka mengetahui bahwa siswa yang aktif bertanya dan menjawab pertanyaan akan mendapatkan nilai yang baik. Dengan cara ini diharapkan dapat menimbulkan semangat siswa untuk aktif dalam diskusi. Guru juga dapat membangkitkan keberanian siswa untuk berbicara dengan menujuk siswa yang bersangkutan untuk bertanya atau menjawab pertanyaan. Guru dapat membantu siswa yang kurang berani berbicara dengan membantunya menjawab pertanyaan atau mengajukan pertanyaan. Guru harus memberikan penghargaan kepada semua siswa yang berani berbicara sekalipun yang disampaikanya tidak sesuai dengan harapan.

3. Terlalu lama jeda waktu siswa untuk menjawab pertanyaan dalam presentasi

Pada sesi tanya jawab, siswa terlalu lama untuk mencari dan mendiskusikan jawaban pertanyaan yang diajukan temannya, kadang berlarut-larut hingga menghabiskan waktu yang 
tidak sedikit. Hal ini perlu segera diatasi. Guru harus mengambil tindakan dengan menyederhanakan pertanyaan yang ada atau mengarahkan jawaban dari pertanyaan tersebut. Guru juga dapat mengarahkan siswa agar meminta bantuan temannya untuk menjawab pertanyaan yang ada. Guru juga dapat mengarahkan siswa agar menjawab terlebih dahulu pertanyaan yang bisa dijawab.

4. Topik pembicaraan melebar tidak sesuai dengan yang diharapkan

Topik pembicaraan dalam diskusi cenderung melebar dan tidak fokus pada tujuan pembelajaran yang diharapkan. Untuk mengatasi hal ini guru harus cepat meluruskan topik pembicaraan dan mengingatkan siswa agar topik pembicaraan tidak menyimpang dari permasalahan yang sedang dibicarakan. Di samping itu permasalahan yang muncul adalah pembicaraan siswa cendrung mengulang-ulang yang disampaikan temannya dan kadang menyimpang dari topik pembicaraan. Untuk mengatasi hal ini guru guru harus selalu mengingatkan siswa tentang topik dan alur pembicaraan

5. Guru membutuhkan persiapan yang matang untuk menerapkan model ini

Untuk menerapkan model pembelajaran CORE, guru harus mempunyi persiapan yang baik agar proses pembelajaran dapat berjalan sesuai dengan tujuan pembelajaran yang diharapkan. Guru harus menyiapkan skenario pembelajaran yang baik agar tahapan-tahapan pembelajaran yang direncanakan dapat dikontrol sesuai dengan skenario yang ada. Guru harus menyediakan media pembelajaran yang akan digunakan untuk memperlancar jalannya pembelajaran. Guru harus mampu memilah materi yang dapat diterapkan degan menggunakan model pembelajaran CORE ini karena tidak semua materi dapat diterapkan dengan model pembelajaran ini. Setiap tahapan Connecting, Organizing, Reflecting, dan Extending harus benar-benar dimunculkan dalam langkah-langkah pembelajaran.

6. Siswa kesulitan merefleksikan hasil pembelajaran

Siswa belum mampu memikirkan kembali, mendalami, dan menggali informasi yang sudah didapat. Siswa masih terbiasa dengan sifat menerima informasi, belum mampu mengolah dan menyaring informasi. Siswa mengalami kesulitan memikirkan kembali informasi-informasi yang sudah didapatkan benar atau salah atau mungkin masih terdapat kekurangan. Siswa masih mengalami kesulitan untuk mengaitkan materi pembelajaran dengan kehidupan dunia nyata. Hanya beberapa siswa saja yang sudah mampu untuk menentukan informasi yang didapat itu benar atau salah dan menghubungkannya dengan kehidupan dunia nyata. Untuk mengatasi hal itu, guru harus memandu siswa untuk mendalami, menggali informasi, dan mengolah informasi yang didapatkan siswa dengan memberikan penguatan-penguatan tentang hal-hal yang sudah dipelajari. Guru membantu siswa menghubungkan setiap detail informasi dengan informassi lain agar siswa dapat menarik kesimpulan secara utuh, sehingga siswa dapat menentukan benar atau salah informassi yang diperolehnya.

7. Siswa kesulitan memperluas pengetahuan (Extending)

Extending merupakan kegiatan untuk mengembangkan, memperluas, menggunakan, dan menemukan pengetahuan. Pada tahap ini siswa mengalami kesulitan untuk dapat memperluas pengetahuan atau informasi yang didapat selama proses berlangsung. Siswa masih terbiasa memahami isi teks secara ekplisit, belum mampu mengambil makna secara implisit dari teks 
yang ada. Hanya siswa tertentu saja yang mampu mengungkapkan makna implisit dari teks cerita fabel yang sudah dipelajari. Siswa belum sampai pada tahap menemukan pengetahuan dari pembelajaran yang sudah ada. Padahal cerita fabel adalah cerita yang berisi sindiran terhadap perilaku kehidupan nyata di tengah masyarakat yang dituangkan dalam bentuk cerita fiksi. Tokoh dengan berbagai karakter perwatakannya adalah sindiran terhadap karakter perilaku kehidupan ditengah masyarakat. Untuk mengatasi hal itu, guru dapat memandu siswa menemukan karakter-karakter orang dilingkungan tempat tiggalnya dan menghubungkannya dengan karakter yang ada dalam cerita. Guru juga dapat menuntun siswa untuk menemukan pesan moral dalam cerita dan menghubungkannya dengan peristiwa nyata yang terjadi di tengah masyarakat. Dengan menarik hubungan isi cerita dengan peristiwa-peristiwa yang terjadi di lingkungan siswa maka siswa sudah melakukan Extending, yaitu mengekplrorasi pembelajaran ke dunia nyata dalam kehidupan sehari-hari.

\section{PENUTUP}

\section{Simpulan}

Model pembelajaran adalah suatu kerangka konseptual yang tergambar dari awal sampai akhir dari proses pembelajaran untuk mencapai tujuan belajar. Salah satu model pembelajaran yang inovatif adalah model pembelajaran CORE. Model CORE (Connecting, Organizing, Reflecting, Extending) adalah suatu model pembelajaran yang memiliki desain mengonstruksi kemampuan siswa dengan cara menghubungkan dan mengorganisasikan pengetahuan, kemudian memikirkan kembali konsep yang sedang dipelajari dan memperluas pemahaman materi dengan pengetahuan diluar teks. Model pembelajaran ini dapat diterapkan pada materi pelajaran bahasa Indonesia, salah satunya pada materi teks cerita fabel. Cerita fabel adalah cerita tentang dunia hewan atau tumbuhtumbuhan yang seolah-ołah bisa berbicara seperti manusia.Teks cerita fabel digunakan sebagai sarana untuk menyampaikan pesan-pesan dan nilai moral kepada pembaca, dengan tujuan agar pembaca tidak mudah tergoda untuk melakukan tindakan tercela.

Hasil penelitian membuktikan bahwa model CORE dapat meningkatkan hasil dan aktivitas pembelajaran siswa pada membaca pemahaman teks cerita fabel.Hasil penilaian pembelajaran menunjukkan hasil yang baik dan aktivitas pembelajaran juga menunjukkan hasil yang baik. Hasil penilaian pembelajaran membaca pemahaman siswa memperoleh nilai rata-rata 82,80 . Aktivitas pembelajaran menunjukkan bahwa siswa antusiasdalam mengikuti kegiatan pembelajaran, siswa aktif dalam kegiatan diskusi dan menutup kegiatan pembelajaran,dan mampu menarik kesimpulan materi yang telah diberikan.

Dalam pelaksanaan pembelajaran dengan menggunakan model pembelajaran CORE dan metode mengajar diskusi terdapat beberapa hambatan dalam pelaksanaannya, yaitu: kekurangan waktu untuk presentasi hasil diskusi, kegiatan diskusi didominasi oleh siswa tertentu, terlalu lama jeda waktu siswa untuk menjawab pertanyaan dalam presentasi, topik pembicaraan melebar tidak sesuai dengan yang diharapkan, guru membutuhkan persiapan yang matang untuk menerapkan model ini, Siswa kesulitan merefleksikan hasil pembelajaran, dan siswa kesulitan memperluas pengetahuan (Extending). 


\section{Saran}

Untuk dapat menerapkan model pembelajaran CORE dengan metode diskusi hendaknya memperhatikan hal-hal berikut:

1. Guru harus mengatur waktu sebaik mungkin agar semua tahapan pembelajaran dapat berjalan sesuai skenario pembelajaran yang diharapkan, termasuk jedah waktu siswa untuk menjawab pertanyaan dalam diskusi kelas.

2. Guru harus mengatur jalannya diskusi dengan baik dan memberikan kesempatan yang sama pada seluruh siswa utuk tampil agar pembicaraan tidak didominasi oleh siswa tertentu saja.

3. Guru harus mengontrol topik pembicaraan diskusi agar fokus pada tujuan pembelajaran yang diharapkan.

4. Guru harus mempersiapkan rencana, skenario, media dan strategi pembelajaran yang matang.

5. Guru harus betul-betul memandu siswa untuk dapat merefleksikan pembelajaran yang berlangsung agar siswa memperoleh makna dari pembelajaran yang terjadi.

6. Guru harus memandu siswa untuk dapat memperluas pengetahuan (Extending) terhadap pembelajaran yang berlangsung.

7. Jika model pembelajaran CORE dapat meningkatkan aktivitas pembelajaran siswa pada membaca pemahaman teks cerita fabel, maka ada kemungkinan model pembelajaran CORE dapat meningkatkan aktivitas pembelajaran pada meteri pelajaran yang lain.

\section{DAFTAR PUSTAKA}

Abidin, Y. (2014). Desain Sistem Pembelajaran dalam Konteks Kurikulum 2013. Bandung: Refika Aditama.

Asih. (2016). Strategi Pembelajaran Bahasa Indonesia. Bandung: Pustaka Setia.

Curwen, M. S., Miller, R. G., White-Smith, K. A., \& Clfee, R. C. (2010). Increasing Teachers' Metacognition Develops Students' Higher Learning during Content Area Literacy Instruction: Findings from the Read-Write Cycle Project. Issues in Teacher Education, 133.

Handayani. (2018). Keefektifan Model Berpikir Induktif dan Model Saintifik pada Pembelajaran Menulis Fabel. Jurnal Pendidikan Bahasa Indonesia Unversitas Islam Sultan Agung, 6(1), $32-41$.

Mahmud. (2011). Metode Penelitian Pendidikan. Bandung: Pustaka Setia.

Miller, R. G., \& Calfee, R. C. (2004). Making Thinking Visible: A Method to Encourage Science Writing in Upper Elementary Grades. California: National Science Teachers Association.

Ngalimun. (2014). Strategi dan Model Pembelajaran. Yogyakarta: Aswaja Pressindo. 
Sani, R. A. (2013). Inovasi Pembelajaran. Jakarta: Bumi Aksara.

Shoimin, A. (2014). 68 Model Pembelajaran Inovatif. Yogyakarta: Ar-Ruzz Media.

Sukmadinata, N. S. (2011). Metode Penelitian Pendidikan. Bandung: Remaja Rosdakarya.

Suyatno. (2009). Menjelajah Pembelajaran Inovatif. Sidoarjo: Masmedia Buana Pustaka.

Yogyakarta, T. P. (2010). Teknik Bercerita. Yogyakarta: Kurnia Kalam Semesta. 